\title{
Effects of Haulm Killing on Seed Potato Quality
}

\author{
E. Virtanen ${ }^{1} \&$ Mervi Seppänen ${ }^{2}$ \\ ${ }^{1}$ MTT Agrifood Research Finland, Biotechnology and Food Research, Oulu, Finland \\ ${ }^{2}$ Department of Agricultural Sciences, University of Helsinki, Helsinki, Finland \\ Correspondence: E. Virtanen, MTT Agrifood Research Finland, Biotechnology and Food Research, P.O.Box \\ 413, 90014 University of Oulu, Oulu, Finland. Tel: 358-40-8432-562. E-mail: elina.virtanen@mtt.fi
}

Received: December 16, 2013 Accepted: January 13, $2014 \quad$ Online Published: February 15, 2014

doi:10.5539/jas.v6n3p168 URL: http://dx.doi.org/10.5539/jas.v6n3p168

\begin{abstract}
In Northern Finland $\left(65^{\circ} 40^{\prime} \mathrm{N}\right)$, haulm killing is used in seed potato production primarily to regulate tuber size. The most common haulm killing method is mechanical-chemical. We studied the effects of mechanical and mechanical-chemical haulm killing methods on seed potato quality, comparing to natural haulm senescence (control). The timing of haulm killing (when no more than $5 \%$ of the crop tubers were over $50 \mathrm{~mm}$ in size) and the time between destruction and harvest (21-26 days) were similar to practices followed in seed-potato production. Matilda was the cultivar used. In this study, haulm killing clearly increased plant disease pressure, as black scurf (Rhizoctonia solani) could be seen in tubers whose haulm had been destroyed. Black scurf was also observed in mechanical haulm killing. The yield from naturally senesced haulms had less black scurf than the other treatments. In addition, when haulm senescence occurred naturally, crop yield and starch content were highest compared to other treatments.
\end{abstract}

Keywords: seed potato, haulm killing, quality, black scurf

\section{Introduction}

Haulm killing can be used to advance harvesting, reduce foliage mass, obtain a suitable tuber size, strengthen tuber skins before harvesting and prevent plant pathogens from spreading amongst the foliage and crop (Struik \& Wiersema, 1999). The aim of haulm killing in seed potato production is particularly to control soil-borne or seed-borne diseases, including viruses, black scurf (Rhizoctonia solani), late blight (Phytophthora infestans), gangrene (Phoma foveata), Verticillium wilt (Verticillium dahliae) and bacteria (Kempenaar \& Struik, 2007).

The haulm can be destroyed using a variety of methods (steaming, flaming, electrocutting, vine pulling and mechanical or chemical methods or combinations of both). In the study of Misener and Everett (1981), different haulm killing methods were compared and haulm pulling to cut off the tubers from the roots was found to be most effective; $98-100 \%$ of the haulm dried and re-growth appeared in only $2-3 \%$. Pulling immediately inhibits haulm starch synthesis, prevents phloem transport of photosynthesis products to the tubers (Tiessen et al., 2002) and prevents the supply of growth-stimulating hormones. Haulm killing would appear to be more effective whatever the method used if carried out once the foliage has already activated natural senescence (van Evert, van der Voet, van Valkengoed, Kooistra, \& Kempenaar, 2012).

Effects of the timing of haulm killing in seed potato production on physiological condition have been studied in different production conditions and cultivars. In their studies, Brown, Beattie, and Laurence (2003) observed that the timing of haulm killing affected the physiological properties of seed potatoes, whereas Wurr, Fellows, Akehurst, Hambidge, and Lynn (2001) observed that the effects of the timing of haulm killing were not clera. According to Struik and Wiersema (1999), differences in disease resistance between cultivars must be taken into consideration in determining the timing of haulm killing. If the cultivar is not highly disease-resistant, it is recommended that the haulm is destroyed earlier than those of more disease-resistant cultivars. The presence of aphids must also be considered, along with the virus infection pressure in the production area. Early haulm killing decreases crop yield but, on the other hand, haulm killing carried out too late increases the risk of pathogens and potato diseases (Struik \& Wiersema, 1999). The use of haulm killing or haulm killing chemicals is recommended when the foliage shows signs of natural senescence, because interrupting its growth while still immature causes crop starch content to remain low, and the physiological condition of tubers used to produce seed potatoes may remain unstable (Kempenaar \& Struik, 2007). 
The effects of the time between haulm killing and harvesting have become apparent primarily in the context of the physiological behaviour of seed potatoes (Wurr et al., 2001; Brown et al., 2003). The recommended time between haulm killing and harvest is 10-14 days. Skin set typically takes 10-14 days, depending on the cultivar and soil conditions (Halderson et al., 1988). If harvest is delayed in excess of the recommended time, there is a real risk of increased infection from plant diseases (Struik \& Wiersema, 1999).

Under northern Europe production conditions, haulm killing is used primarily as a method of controlling tuber size, as tuber growth is relatively quick in long-day conditions (Temmerman et al., 2002). Haulm killing is often carried out on highly immature plants that may still be flowering, and the timing of haulm killing is not synchronized with foliage senescence or potato tuber maturation. When haulm killing has to be carried out at a relatively early stage, the time between destruction and harvest can be easily prolonged for as long as three or four weeks if weather conditions permit. In the present study we examined whether the methods and the chemicals used in the haulm killing practices of seed potato production affect seed-potato crop variables (crop yield), starch content and external quality).

\section{Materials and Methods}

\subsection{Field Experiments}

The soil type in the field plots was medium fine sand, with $\mathrm{pH}$ between 5.8-6.2. The plots were cultivated in 3 -year crop rotation with barley as a rotation crop. The preparation of field plots was carried out according to normal cultivation practise: ploughing in autumn, seedbed preparation by S-tine harrow and horizontal rotary cultivator (Juko, Finland) in spring. The fertiliser used in the experiments was Potato Y1 (NPK 8-5-19 CCF) and the level of nitrogen fertiliser was $60 \mathrm{~kg} \mathrm{ha}^{-1}$. Field experiments were planted by semi-automatic planting machine (Kuppi-Juko, Finland) with $80 \mathrm{~cm}$ row-spacing and $28 \mathrm{~cm}$ planting density, between 19 May-6 June. Rimsulfuron $\left(250 \mathrm{~g} \mathrm{~kg}^{-1}, 30+20 \mathrm{~g} \mathrm{ha}^{-1}\right.$ at $3001 \mathrm{H}_{2} \mathrm{O}$, Titus ${ }^{\circledR}$ WSB, Berner) was used for weed control. The experimental squares were $3.2 \mathrm{~m} \mathrm{x} 10.0 \mathrm{~m}$ in size, with four replications. The cultivar was the mid-to-late maturing Matilda, seed class E2.

\subsection{Observations and Haulm Killing Treatments}

After planting, we recorded the days to emergence, the developmental stages as defined by Hack et al. (1993) and observations of any foliage diseases. Temperature data were recorded regularly by the Finnish Meteorological Institute, Oulunsalo weather station (64.9 N, 25.4 E). The temperature calculations from the growing seasons were compared to the long-term averages (Table 1).

Table 1. Weather data representing average temperature sums $\left({ }^{\circ} \mathrm{C}\right)$ and precipitation $(\mathrm{mm})$ during the experiments. Data collected by the Finnish Meteorological Institute, Oulunsalo weather station (64.9 N, 25.4 E) April to September.

\begin{tabular}{lllllllll}
\hline \multicolumn{3}{c}{$\begin{array}{c}\text { Average temperature sums }\left({ }^{\circ} \mathrm{C}\right) \\
\text { 20 years }\end{array}$} & & \multicolumn{4}{c}{ Precipitation $(\mathrm{mm})$} \\
& year 1 & year 2 & year 2 & means & year 1 & year 2 & year 3 & means \\
\hline April & 168 & 173 & 141 & 105 & 37 & 28 & 83 & 40 \\
June & 388 & 475 & 366 & 351 & 66 & 26 & 7 & 61 \\
July & 824 & 862 & 810 & 678 & 88 & 72 & 83 & 78 \\
August & 1068 & 1198 & 1086 & 928 & 66 & 51 & 31 & 64 \\
September & 1106 & 1303 & 1211 & 1034 & 67 & 59 & 14 & 54 \\
\hline
\end{tabular}

The timing of haulm killing was determined by test harvesting during the growing season, and the haulm was crushed when no more than $5 \%$ of the crop tubers were over $50 \mathrm{~mm}$ in size. The target of yield tuber size was $35-55 \mathrm{~mm}$. At the times of haulm killings, the foliage showed only a few signs of natural senescence. Mechanical

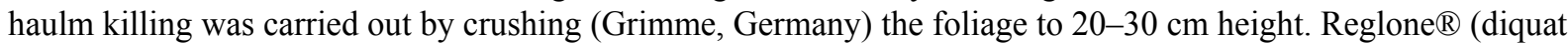
dibromide, $200 \mathrm{~g} / \mathrm{l}$ at 300 l/ha, Syngenta Crop Protection) or Spotlight Plus (carfentrazone-ethyl $60 \mathrm{~g} / \mathrm{l}$ at $300 \mathrm{l} / \mathrm{ha}$, Berner) were used for chemical haulm killing treatments two days after mechanical haulm killing (Table 2). As a control, the haulm was left to naturally senesce until harvest. The efficiency of chemical haulm killing was observed as browning of the green parts of the foliage on a $0-100 \%$ scale at $3,7,14$ and 21 days after the chemical 
was sprayed. The efficiency of mechanical crushing was assessed as a percentage of the haulm covered, with the condition following haulm crushing used as comparison. The re-growth of foliage was assessed on a scale of $0-100(0=$ no growth, $100=$ growth in each plant $)$.

Table 2. Haulm killing treatments carried out in the field experiments

\begin{tabular}{ll}
\hline & Treatment \\
\hline Natural senescence & - \\
Mechanical & Haulm crushing \\
Mechanical-chemical 1 & $\begin{array}{l}\text { Crushing + Reglone } 1.5 \mathrm{l} / \mathrm{ha} \\
\text { (diquat dibromide 200 g/l) }\end{array}$ \\
Mechanical-chemical 2 & $\begin{array}{l}\text { Crushing + Spotlight Plus 1.0 1/ha } \\
\text { (carfentrazone-ethyl } 60 \mathrm{~g} / \mathrm{l})\end{array}$ \\
\hline
\end{tabular}

Table 3. Dates of planting, haulm killing, days after planting (DAP) and harvesting, days after haulm killing (DAH)

\begin{tabular}{|c|c|c|c|c|}
\hline \multirow{2}{*}{$\frac{\text { Year }}{1 .}$} & \multirow{2}{*}{$\begin{array}{l}\text { Planting } \\
6.6 .\end{array}$} & \multicolumn{2}{|c|}{ Haulm killing } & \multirow{2}{*}{$\frac{\text { Harvesting }}{26 \text { DAH (3.9.) }}$} \\
\hline & & 58 DAP & (3.8. mechanical) & \\
\hline & & & (8.8. chemical) & \\
\hline \multirow[t]{2}{*}{2.} & 21.5 & 97 DAP & (26.8. mechanical) & 21 DAH (18.9.) \\
\hline & & & (28.8.chemical) & \\
\hline \multirow[t]{2}{*}{3.} & 19.5 & 85 DAP & (12.8. mechanical) & 21 DAH (2.9.) \\
\hline & & & (14.8. chemical) & \\
\hline
\end{tabular}

\subsection{Yield and Quality Analyses}

Harvesting (Underhaug 2100 harvester, Norway) was carried out 21-26 days after haulm killing (Table 3). Yields per plot were determined by weighing (Mettler, Germany, accuracy 0.02) and the tubers graded (SKALS RB814, Sweden) according to size $(<35 \mathrm{~mm}, 35-55 \mathrm{~mm}, 55-70 \mathrm{~mm}$ and $>70 \mathrm{~mm})$. Starch content (specific gravity: $214.53 \times$ (air weight/(air weight - water weight) - 217.76) and the external quality of the tubers was analysed by plot based on the 35-70 mm sized tubers. External quality was assessed visually by separating healthy and damaged tubers according to damage category. Damage was divided into the following categories: damage caused by disease $(1=$ healthy; $2-5=$ damage types such as: scab, black scurf, soft rot, blackleg, other fungal or bacterial diseases; $6-10=$ damage from physiological or other causes: turgor split, growth crack, misshape, greening, black spot, hollow heart, internal necrosis, other). The tubers in each damage category were weighed and the quantity of each damage type was calculated as a percentage of weight. As an additional definition of external quality, the quantity of black scurf was observed separately in each tuber as a percentage of tuber surface. In the analyses, the regulations concerning seed potato certification inspections were taken into consideration. These allow a maximum of $3 \%$ by weight of black scurf, skin spot and deep-scab (where the scab-covered area is more than one tenth of the tuber surface). In addition, the area covered by black scurf and common scab (where the area covered by common scab is over one third of the tuber surface) must not exceed $5 \%$ of the sample. Tubers below the certification limits were classified as healthy.

\subsection{Statistical Analyses}

The experimental model was fully randomized complete block. The statistical analyses were conducted using the Mixed Procedure from the SAS 9.2/SAS Enterprise Guide 4.3 (SAS Institute Inc., Cary, NC, USA) program, using a variance analysis model in balanced data from randomized complete block with means comparisons and contrasts.

\section{Results}

\subsection{Observations and Haulm Killing Treatments}

The foliage of the field experiments developed normally, emergence lasted 17-19 days after planting. $R$. solani stolon canker on potato stems was observed in $0-3.5 \%$ of all the plants. The $R$. solani infected plants were found to be scattered around the field experiment areas. Other foliage diseases were not observed. Mechanical-chemical 
haulm killing was effective, destroying the haulm completely in two weeks (Figure 1). Of the chemicals, diquat dibromide $(200 \mathrm{~g} / \mathrm{l})$ acted faster than carfentrazone ethyl $(60 \mathrm{~g} / \mathrm{l})$, but a little re-growth $(12 \%)$ was observed when diquat dibromide was used. Re-growth was also observed (24\%) annually when only mechanical treatment was used.

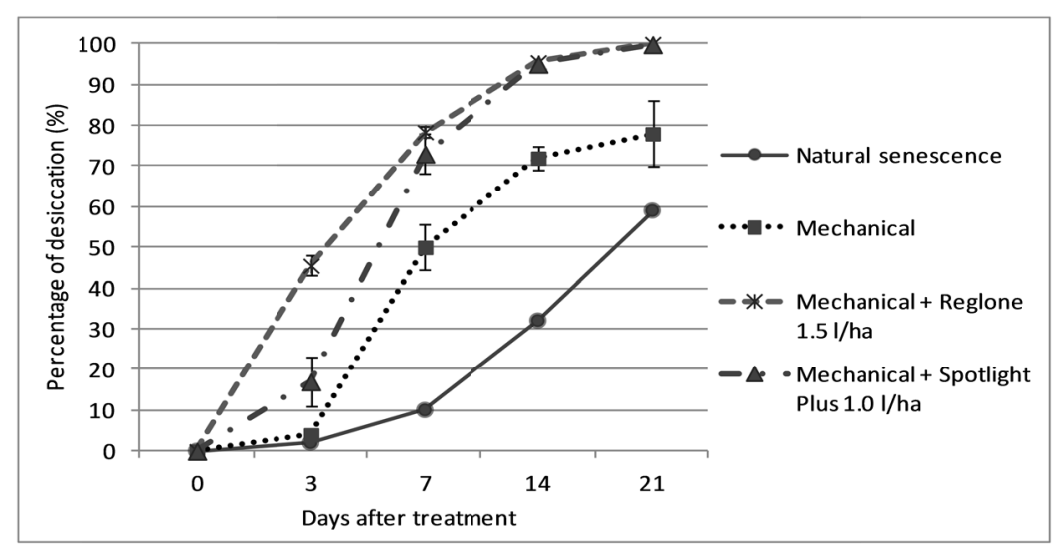

Figure 1. Potato leaf and stem desiccation visually rated at 3, 7, 14 and 21 days after treatments on a linear scale of $0-100,0=$ no effect, $100=$ total kill of haulm

\subsection{Yield and Quality Analyses}

Naturally senesced haulm produced the largest yield ( $40.3 \mathrm{t} / \mathrm{ha}, \mathrm{p}=<0.001$ on average) and the tuber starch content $(17.2 \%, p=<0.001)$ reached the level typical of the cultivar (Figure 2). On average, mechanical haulm killing affected yield and starch contents in the same way as mechanical-chemical haulm killing. At the annual level, the variance was such that during the first year, both the yield $(31.4 \mathrm{t} / \mathrm{ha}, \mathrm{p}=0.012)$ and starch content $(14.8 \%$, $\mathrm{p}=0.025$ ) were higher in mechanical haulm killing than in mechanical-chemical haulm killing. During the next two years, there were no significant differences. The average mechanical-chemical yield level was $29.2 \mathrm{t} / \mathrm{ha}$ and starch content varied between $12.3-15.8 \%$. The smallest $<35 \mathrm{~mm}$ part, $7 \%$ of the total yield, was produced by the control (natural senescence). In mechanical haulm killing, $<35 \mathrm{~mm}$ size was $17 \%$, and $20 \%$ in mechanical-chemical haulm killing. The proportion of $35-55 \mathrm{~mm}$ was $71 \%$ in the control (natural senescence), $78 \%$ in mechanical haulm killing and $76 \%$ on average in mechanical-chemical haulm killing. Only naturally senesced haulm produced $>70$ mm tubers (Table 4).

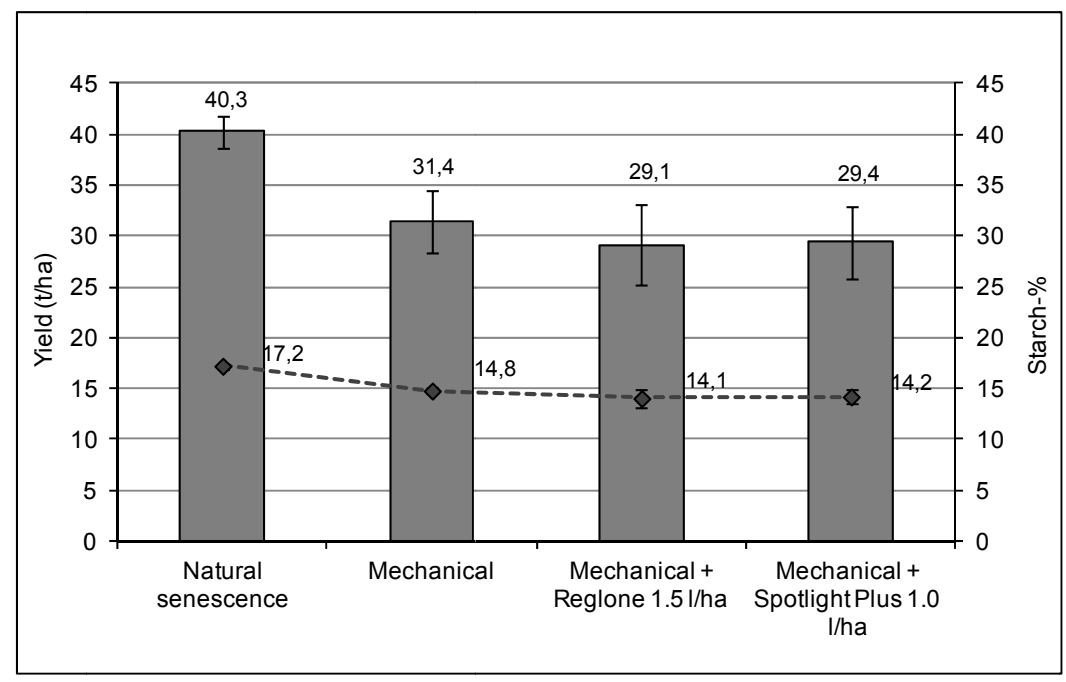

Figure 2. The values are the averages of three years. Bars represent yield and $\downarrow$ symbols starch content 
There was abundant black scurf in the tubers (Figure 3). The incidence of black scurf varied between 0-60\% by treatments and there was differences between the years. In the first two years, mechanical-chemical haulm killing increased the occurrence of black scurf $(30 \%$ on average) to a statistically significant degree ( $\mathrm{p}=>0.001)$ compared to other treatments. Mechanical haulm killing also increased the occurrence of black scurf $(27 \%$ on average, $\mathrm{p}=0.028$ ) compared to naturally senesced haulm. During the final year, there were no statistically significant differences between treatments with regard to the presence of black scurf. No other plant diseases were found except the presence of few mechanically damaged tubers (results not shown).

Table 4. Re-growth (\%) after haulm killing and effects of haulm killing (cultivar Matilda) on seed potato yield $(\mathrm{t} / \mathrm{ha})$, tuber size distribution (\%), starch content (\%) and black scurf (R. solani) $(\%)$ in yield

\begin{tabular}{|c|c|c|c|c|c|c|c|c|}
\hline & $\begin{array}{l}\text { Re-growth } \\
(\%)\end{array}$ & $\begin{array}{l}\text { Yield } \\
\text { t/ha }\end{array}$ & $<35$ & $35-55$ & $55-70$ & $>70$ & $\begin{array}{l}\text { Starch- } \\
\%\end{array}$ & $\begin{array}{l}\text { Black } \\
\text { scurf } \\
(\%)\end{array}$ \\
\hline \multicolumn{9}{|l|}{ Year 1.} \\
\hline No haulm killing & - & $36.9^{* * *}$ & 4.2 & 75.7 & 15.0 & 5.1 & $17.4^{* * *}$ & 0.0 \\
\hline Mechanical & 32 & $24.3^{* *}$ & 17.9 & 79.8 & 2.3 & 0.0 & $14.2^{* *}$ & 0.5 \\
\hline Mechanical+Regone 1.5 1/ha & 18 & 20.1 & 19.5 & 78.3 & 2.2 & 0.0 & 12.3 & $36.8^{* * *}$ \\
\hline Mechanical+Spotlight 1.01 /ha & - & 20.9 & 17.9 & 79.6 & 2.5 & 0.0 & 12.8 & $29.3^{* * *}$ \\
\hline \multicolumn{9}{|l|}{ Year 2.} \\
\hline No haulm killing & - & $41.0^{* * *}$ & 5.4 & 67.1 & 20.1 & 7.4 & $17.5^{* * *}$ & 10.9 \\
\hline Mechanical & 29 & 34.3 & 13.2 & 78.4 & 8.4 & 0.0 & $14.7^{*}$ & $38.7^{* * *}$ \\
\hline Mechanical+Regone 1.5 1/ha & 9 & 33.6 & 15.3 & 77.3 & 7.4 & 0.0 & 15.8 & $62.5^{* * *}$ \\
\hline Mechanical+Spotlight 1.0 1/ha & - & 33.6 & 14.4 & 78.4 & 7.2 & 0.0 & 15.4 & $60.6^{* * *}$ \\
\hline \multicolumn{9}{|l|}{ Year 3.} \\
\hline No haulm killing & - & $43.0^{* * *}$ & 11.1 & 71.0 & 11.7 & 6.3 & $16.7^{* *}$ & 13.0 \\
\hline Mechanical & 10 & 35.5 & 20.5 & 77.9 & 1.6 & 0.0 & 15.5 & 12.4 \\
\hline Mechanical+Regone $1.5 \mathrm{l} / \mathrm{ha}$ & 8 & 33.7 & 25.9 & 71.4 & 2.7 & 0.0 & 14.0 & 18.9 \\
\hline Mechanical+Spotlight 1.0 1/ha & - & 33.5 & 22.9 & 77.0 & 0.1 & 0.0 & 14.5 & 16.2 \\
\hline \multicolumn{9}{|l|}{ Means } \\
\hline No haulm killing & - & $40.3^{* * *}$ & $7.1^{* * *}$ & 71.0 & $15.6^{* * *}$ & $6.3^{* *}$ & $17.2^{* * *}$ & 7.9 \\
\hline Mechanical & 24 & $31.4^{*}$ & 17.2 & 78.1 & 4.7 & 0.0 & $14.8^{*}$ & $17.2^{* *}$ \\
\hline Mechanical+Regone 1.5 1/ha & 12 & 29.1 & 20.2 & 75.7 & 4.1 & 0.0 & 14.1 & $39.4^{* * *}$ \\
\hline Mechanical+Spotlight 1.0 1/ha & - & 29.4 & 20.3 & 77.1 & 2.5 & 0.0 & 14.2 & $35.3^{* * *}$ \\
\hline
\end{tabular}

Statistically significant differences between haulm killing treatments at $* \mathrm{P}=0.05, * * \mathrm{P}=0.01$ and $* * * \mathrm{P}=0.001$. There were no significant interactions between treatments and other variables measured.

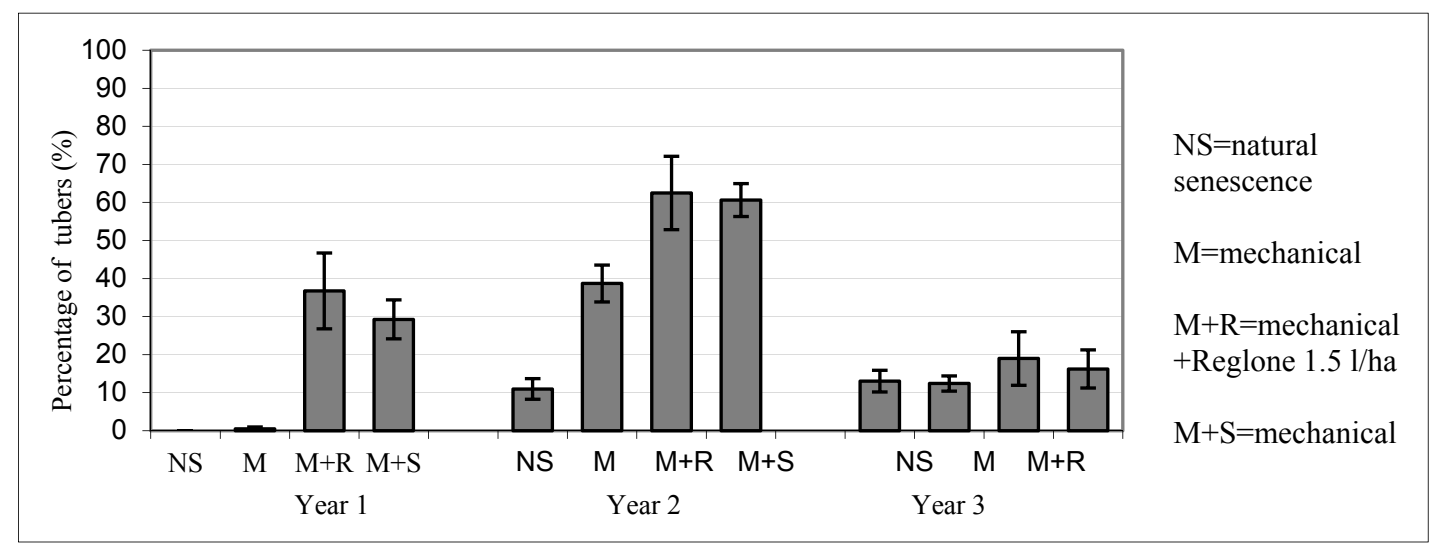

Figure 3. Percentage of tubers infected with black scurf (contamination area $>10 \%$ of the tuber surface) among the yields by treatments based on analyses of external quality 


\section{Discussion}

\subsection{Haulm Killing Treatments}

When haulm killing is used to regulate tuber size in short growing-season production conditions, in many cases, the haulm must be destroyed while still completely green and capable of photosynthesis. Earlier studies have found that in order to reach adequate efficiency, more chemicals are needed to destroy vital foliage than to destroy more senesced foliage (van Evert et al., 2012). To keep the use of haulm-killing chemicals at a reasonable level, additional tuber growth and photosynthesis can be efficiently interrupted by means of mechanical-chemical haulm killing.

The differences between the efficiency of the chemicals used for haulm killing are generally small. In earlier studies, as well as in our study, diquat was found to have a slightly more rapid effect than other chemicals (Ivany, 2001). Mechanical haulm killing also works well (Waterer, 2007). However, when applied to immature foliage, our study showed re-growth after crushing. Re-growth and reformation of photosynthetic capacity manifested as increased yield levels following mechanical haulm killing, compared to mechanical-chemical haulm killing under the first year. The results were contrary to the studies of Waterer (2007) in which the yield levels after mechanical haulm crushing were lower in comparison to yield levels after mechanical-chemical haulm crushing. Compared to other haulm killing methods, re-growth was least when following haulm pulling (Misener \& Everett 1981; Halderson et al., 1988), because disconnecting foliage from the roots leads to instant cessation of phloem transport and interruption of growth (Tiessen et al., 2002). After haulm killing, previously synthesized metabolites may continue to increase in the still green stems and the remaining bottom leaves (Halderson et al., 1988) and growth-stimulating hormones have an opportunity to exert their effect on re-growth (Tiessen et al., 2002). Regardless of the method used, haulm killing would be most efficient if carried out at the time when the haulm has already started to senesce naturally (van Evert et al., 2012). Haulm vitality at the end of the growing season varies with weather conditions, production management and potato variety.

\subsection{Yield and Quality}

It is possible to regulate tuber size distribution by means of haulm killing; however this is achieved at the cost of yield and starch content. As a method of controlling tuber size mostly between $35-55 \mathrm{~mm}$, haulm killing is easy to implement, and $70-80 \%$ of the tubers were distributed in the preferred size in our study. According to Struik and Wiersema (1999), the lower starch content and yield produced by haulm killing, as compared to the yields produced by natural senescence, are the natural result of haulm killing carried out at an early stage. When haulm killing is used in seed potato production primaly to achieve optimal tuber size distribution for commercial purposes, the physiological state of seed potatoes cannot be predicted. In addition to physiological state, the relatively low starch content of seed potatoes to which haulm killing is applied, may affect their vitality (Sabba et al., 2007) to produce new sprouts and roots during the next growing season.

The 10-14 day interval between haulm killing and harvest is considered adequate in terms of periderm maturity, depending on the cultivar (Waterer, 2007). Skin set typically takes 10-14 days, depending on the cultivar and soil conditions (Halderson et al., 1988). In northern seed potato production conditions, haulm killing is applied to immature plants and harvest is delayed as long as over 3 weeks after the haulm killing, weather conditions permitting. Tuber crops are known to be exposed to infection by black scurf when the haulm is destroyed while the root system is still in operation and the time between haulm killing and harvest is prolonged (Tsror, 2010). Black scurf caused by $R$. solani (Kühn AG-3) leads to substantial economic losses (Lootsma \& Scholte, 1996), and in seed potato production, it may be an obstacle to certification. In our study, mechanical-chemical haulm killing in particular increased black scurf. The results are similar to those of Dijst (1988) where chemical haulm killing and cutting the stems, along with the prolonged period of time between haulm killing and harvest stimulated the formation of black scurf. According to Dijst (1988), water-insoluble components enable the formation of scleroses on the tuber surfaces, and the changes taking place in the relationship of inhibiting and stimulating factors after haulm killing could influence sclerosis formation. In addition, the colonisation by $R$. solani on the ground before harvest is a factor that significantly influences the occurrence of black scurf in tubers (Lootsma \& Scholte, 1996). According to Lootsma and Scholte (1996), weather conditions are also significant in terms of the occurrence of $R$. solani, and wet and low temperatures favour its development. In this study, black scurf occurrence in tubers was the lowest after a dry growing season and the highest after cool and more moist conditions.

The results of our study showed that in seed potato production, the timing of haulm killing should not be determined only by tuber size even if the haulm killing methods in use work effectively. The best-selling part of the yield in terms of tuber size may be lost because of a plant disease. More research is needed to optimize haulm 
killing and to suppress different soil-borne and seed-borne diseases. Even though haulm killing can decrease virusor other seed- or soil-transmitted plant diseases in seed potato production, some haulm-killing methods or production conditions may, however, further the incidence of plant diseases (Kempenaar et al., 2008; Dijst, 1988). Production- and cultivar-specific demands must be taken into consideration (Ivany \& Sanderson, 2001; Pavlista, 2001; Bethke \& Busse, 2010) and sensors or other methods need to be developed to determine the timing or the amounts of chemicals used for haulm killing (van Evert et al., 2012). Our study provides significant information regarding haulm killing in the northern conditions (latitudes $65^{\circ} 40^{\prime} \mathrm{N}$ ), specifically to the as well as seed potato production of the cultivar Matilda. In this case haulm killing in seed potato production is questionable since total yield and starch content was lower and black scurf infection higher compared to the control.

\section{References}

Bethke, P. C., \& Busse J. S. (2010). Vine-Kill treatment and harvest date have persistent effects on tuber physiology. American Journal of Potato Research, 87, 299-309. $\mathrm{http} / / \mathrm{dx}$.doi.org/10.1007/s12230-010-9137-4

Brown, P. H., Beattie, B., \& Laurence, R. (2003). Intergenerational effects on seed potato physiological aging. Acta Horticulture, 619, 241-249.

Dijst, G. (1988). Effect of periderm and water-soluble exudates of potato tubers on black scurf formation before and after haulm destruction. Netherlands Journal of Plant Pathology, 94, 247-266. http//dx.doi.org/10.1007/BF01977316

Hack, H., Gall, H., Klemke, T., Klose, R., Meier, U., Stauss, R., \& Witzenberger, A. (1993). The BBCH-scale for phonological growth stages of potato (Solanum tuberosum L.). Proceedings of the 12th Annual Congress of the European Association for Potato Research, Paris, 153-154.

Halderson, J. L., Haderlie, L. C., \& Skrobacki, A. (1988). Mechanical vine killing of potatoes. American Potato Journal, 65, 415-423. http//dx.doi.org/10.1007/BF02852962

Ivany, J., \& Sanderson, J. (2001). Response of potato (Solanum tuberosum) cultivars to glufosinate-ammonium and diquat used as desiccants. Weed Technology, 15, 341-345.

Kempenaar, C., \& Struik, P. C. (2007) Haulm killing. Potato Research, 50, 341-345. http//dx.doi.org/10.1007/s11540-008-9082-5.

Lootsma, M., \& Scholte, K. (1996). Effects of soil disinfection and potato harvesting methods on stem infection by Rhizoctonia solani Kühn in the following year. Potato Research, 39, 15-22. http//dx.doi.org/10.1007/BF02358202

Misener, G. C., \& Everett, C. F. (1981). Vine pulling as a means of top killing potatoes. American Potato Journal, 58, 103-109. http//dx.doi.org/10.1007/BF02854379

Pavlista, A. (2001). Hydrothol as a vine desiccant of Atlantic Potatoes. Journal of Vegetable Crop Production pitää olla kursiivi, 7, 59-68. http://dx.doi.org/10.1300/J068v07n01_08

Sabba, R. P., Bussan, A. J., Michaelis, B. A., Hughes, R., Drilias, M. J., \& Glynn, M. T. (2007). Effect of planting and vine-kill timing on sugars, specific gravity and skin set in processing potato cultivars. American Journal of Potato Research, 84, 205-215. http://dx.doi.org/10.1007/BF02986270

Struik, P. C., \& Wiersema, S. G. (1999). Seed Potato Technology. The Netherlands: Wageningen Pers.

Temmerman, L., Wolf, J., Colls, J., Bindi, M., Fangmeier, A., Finnan, J., Ojanperä, K., \& Pleijel, H. (2002). Effect of climatic conditions on tuber yield (Solanum tuberosum L.) in the European "CHIP" experiments. European Journal of Agronomy, 17, 234-355. http://dx.doi.org/10.1016/S1161-0301(02)00064-3

Tiessen, A., Hendriks, J. H., M., Stitt, M., Branscheid, A., Gibon, Y., Farré, E. M., \& Geigenberg, P. (2002). Starch synthesis in potato tubers is regulated by post-translational redox modification of ADP-glucose pyrophosphorylase: A novel regulatory mechanism linking starch synthesis to the sucrose supply. The Plant Cell, 14, 2191-2213. http://dx.doi.org/10.1105/tpc.003640

Tsror, L. (2010). Biology, epidemiology and management of Rhizoctonia solani on potato. Journal of Phytopathology, 158, 649-658. http://dx.doi.org/10.1111/j.1439-0434.2010.01671.x

van Evert, F. K., van der Voet, P., van Valkengoed, E., Kooistra, L., \& Kempenaar, C. (2012). Satellite-based herbicide rate recommendation for potato haulm killing. European Journal of Agronomy, 43, 49-57. http://dx.doi.org/10.1016/j.eja.2012.05.004 
Waterer, D. (2007). Vine desiccation characteristics and influence of time and method of top kill on yields and quality of four cultivars of potato (Solanum tuberosum L.). Canadian Journal of Plant Science, 87, 129-135. http://dx.doi.org/10.4141/P06-074

Wurr, D. C. E., Fellows, J. R., Akehurst, J. M., Hambidge, A. J., \& Lynn., J. R. (2001). The effect of cultural and environmental factors on potato seed tuber morphology and subsequent sprout and stem development. Journal of Agricultural Science, Cambridge, 136, 55-63. http://dx.doi.org/10.1017/S0021859600008431

\section{Copyrights}

Copyright for this article is retained by the author(s), with first publication rights granted to the journal.

This is an open-access article distributed under the terms and conditions of the Creative Commons Attribution license (http://creativecommons.org/licenses/by/3.0/). 